\title{
National-Cultural Autonomy and 'Neutralism': Vladimir Medem's Marxist Analysis of the National Question, 1903-19201
}

\author{
Roni Gechtman Mount Saint Vincent University
}

\begin{abstract}
Résumé
Le présent article explore les points de vue sur la « question nationale » exprimés par Vladimir Medem (1879-1923) —dirigeant et théoricien notoire du Mouvement international des travailleurs juifs, dans la Russie des Tsars, puis, après 1918, dans la Pologne indépendante-, dans des discussions internes au Mouvement, ainsi que dans ses œuvres théoriques. L'article montre que Medem entendait élaborer un programme politique pour le Mouvement, mais aussi établir le fondement d'une analyse théorique complète de la nation vue sous un angle socialdémocrate (c.-à-d. marxiste). Medem, qui était fortement opposé au nationalisme sous toutes ses formes, a proposé comme modèle de rechange à l'État-nation (qu'exigeaient tous les mouvements nationalistes) l'« État des nationalités », où la citoyenneté, nationalement neutre, serait accordée équitablement aux ressortissants de toutes les nationalités. Medem suggérait en même temps que l'État protège activement les minorités nationales, en leur accordant à chacune une autonomie nationale-culturelle comportant un droit de juridiction limité sur les questions culturelles (et uniquement culturelles). J'estime que l'analyse de la question nationale effectuée par Medem et le programme d'autonomie nationale-culturelle du Mouvement international des travailleurs juifs sont particulièrement dignes d'intérêt (comme les opinions similaires exprimées par les théoriciens austro-marxistes Karl Renner et Otto Bauer); multiculturalistes avant l'heure, ces approches peuvent s'avérer particulièrement utiles aux sociétés d'aujourd'hui, de plus en plus diverses et multiculturelles.
\end{abstract}

\begin{abstract}
:
This article examines the views of Vladimir Medem (1879-1923) - a major leader and theorist of the Jewish Labour Bund in Tsarist Russia and, after 1918, in independent Poland- on the 'national question', as he presented them in internal discussions within the Bund and in his theoretical works. It demonstrates that Medem's goal was not just to outline a political program for the Bund but to establish the foundations for a comprehensive theoretical analysis of the nation from a social democratic (ie. Marxist)
\end{abstract}

\footnotetext{
${ }^{1}$ Research for this article was supported by a Mount Saint Vincent University grant, which I gratefully acknowledge. I would like to thank Adriana Benzaquén and the two anonymous reviewers for their insightful comments and suggestions. Unless otherwise stated, all translations are mine.
} 


\section{National-Cultural Autonomy and 'Neutralism': Vladimir Medem's Marxist Analysis of the National Question, 1903-1920}

perspective. Strongly opposed to nationalism in all its manifestations, Medem put forward, as an alternative to the nation-state (demanded by all nationalist movements), a model of a 'state of nationalities' in which citizenship would be nationally neutral and granted equally to the members of all nationalities. At the same time, Medem proposed that the state must take an active role in protecting national minorities by granting each of them a national-cultural autonomy with a limited jurisdiction over cultural matters (and only those matters). Medem's analysis of the national question and the Bund's program of national-cultural autonomy (like the similar views formulated by Austro-Marxist theorists Karl Renner and Otto Bauer) deserve special attention, I argue; as a form of 'multiculturalism avant la lettre', they may offer insights relevant to today's increasingly diverse and multicultural societies.

\section{Introduction}

The 'national question' was the term used by early-twentieth-century European socialists to refer to the set of problems arising from the coexistence of different ethnic, cultural or national groups within one state, particularly in the Russian, Austro-Hungarian and Ottoman empires. The rise of nationalist political movements throughout the nineteenth century and the creation of new states (Italy, Germany, Bulgaria, Romania, Serbia, and so forth) had not only destabilized the European balance of power and threatened the multinational empires but also posed a conceptual challenge to groups and individuals attempting to understand human society. While the national question was thus a hotly debated topic in Europe in general at the turn of the twentieth century, for socialists and Marxists it raised a significant dilemma because their main goal - the emancipation of the international working class - often entered into conflict with the goals of nationalist movements.

By the early twentieth century, virtually no work within the Marxist tradition offered a convincing analysis of the national question. The reason for this philosophical or theoretical weakness may be found in the fact that the 'founding fathers', Karl Marx and Friedrich Engels, had focused most of their attention on the categories of class and production, which they put at the centre of their analysis of history and society, and thus they had not examined the national question systematically in any of their major theoretical writings. ${ }^{2}$ As a corollary, later Marxist writers construed nation (or nationality) as one of the non-material or superstructural aspects of human reality, dependent on human consciousness and subjectivity. Theorist Chantal Mouffe characterizes this early version of Marxism that considered social classes as the only possible historical subjects as 'class reductionism' (Mouffe, 1979). Subsumed under the category of class, nation seemed not to deserve special theoretical treatment.

\footnotetext{
${ }^{2}$ Marx and Engels did write a series of journalistic articles discussing current events such as the national turmoil in Germany, Ireland, Poland and the different areas of the Austrian and Ottoman empires in the 1840 s to 1890 s, but these articles did not develop a systematic, consistent theory or position. See the series of articles by Marx and Engels collected in Haupt, Lowy and Weill (1974: 64-110).
} 


\section{National-Cultural Autonomy and 'Neutralism': Vladimir Medem's Marxist Analysis of the National Question, 1903-1920}

Some of the most radical among Marx's early followers (such as Rosa Luxemburg and Leon Trotsky) concluded that the very idea of nation should be scorned, that the proletariat must group politically on the basis of international class and leave national differences behind, and that the best solution to the national question would be to eliminate national differences altogether, or at least that what Engels had called the 'non-historical' nations (for example, the Czechs, Slovaks, or Ukrainians) must assimilate into the national majorities of their states (Germans, Hungarians, Russians). ${ }^{3}$ However, many Marxist political activists and theorists of the generation following Marx's, in particular in Central and Eastern Europe, faced a political reality that made ignoring the problems arising from the existence of national differences, and the oppression of certain nations by others, impossible. Such was the case of the social-democratic parties in Austria and Russia, in particular those whose objective was to organize and represent the working classes of the national minorities. Indeed, the most interesting Marxist theories on the national question were produced by members of these parties, such as the Austro-Marxist Karl Renner and Otto Bauer and the Bundist Vladimir Medem, who is the focus of this article. ${ }^{4}$ These Marxist thinkers and activists opposed both the aims and the tactics of nationalism but, unlike other Marxists, they took the national question seriously and argued that it was urgent that ways be found to ensure the peaceful and equal coexistence of different nations (understood as such) within multinational states. Their theoretical analyses and programmatic proposals on the national question are of historical interest since they represent alternatives to the international political order established at the end of the Great War and to the understanding of nationality and nationalism that became hegemonic since that time, synthesized in the phrase 'one nation - one state.' Yet I want to suggest that these analyses have more than historical significance, since the problems Renner, Bauer and Medem addressed were not solved by the new international order and continue to beset the increasingly diverse societies of our own time, whether in states formally defined as

\footnotetext{
${ }^{3}$ The term 'non-historical' nations (or 'nations without history', geschichtslosen Völker) was used mainly by Engels to mean nations that never had a state of their own in the past and were destined to disappear in the future. One might cite a number of pronouncements to this effect, in particular in Engels' journalistic articles. For example, Engels wrote in 1848, referring to the Poles: "A French historian has said: Il y a des peuples nécessaires - there are necessary nations. The Polish nation is undoubtedly one of the necessary nations of the nineteenth century" (350). See also Engels, "The Magyar Struggle" (1849). Marx, to avoid the Hegelian implications of the terms 'nations with and without history', preferred the more flexible terms 'revolutionary and counterrevolutionary nations'. Yet the meaning seems to be the same in both cases (see Haupt and Weill, 1980: 17-18). For a pointed criticism of Engels' concepts of 'historical' and 'non-historical' nations by a scholar who nevertheless acknowledges his debt to Marxian thought, see Wolf (1997), especially xi-xiv, 4-7.

${ }^{4}$ The recent English translations of Renner's and Bauer's major works on the national question have made them available for the first time to scholars in the English-speaking world. See Renner (2005), originally published in 1899 as Synopticus [Karl Renner], Staat und Nation. Zur österreichischen Nationalitätenfrage. Staatsrechtliche Untersuchung über die möglichen Principien einer Lösung und die juristischen Voraussetzungen eines Nationalitätengesetzes. Bauer's Question of Nationalities and Social Democracy (2000) was originally published in 1907 as Die Nationalitätenfrage und die Sozialdemokratie. On Renner's and Bauer's views on the national and Jewish questions, see Gechtman (2005a).
} 


\section{National-Cultural Autonomy and 'Neutralism': Vladimir Medem's Marxist Analysis of the National Question, 1903-1920}

nation-states but in fact inhabited by several national groups or in industrialized and postindustrialized societies with large and growing proportions of immigrants. As German scholar Gertrud Pickhan claims, what the Austro-Marxists and Bundists envisioned was a form of 'multiculturalism avant la lettre' (Pickhan, 2004). ${ }^{5}$

This is the context within which I will examine Medem's theorization of the national question. Vladimir Medem (1879-1923) was a prominent leader of the Jewish Labour Bund in the Russian Empire in the first decade of the twentieth century and the party's main theorist of the national question. ${ }^{6}$ Although during his lifetime Medem was never the Bund's official leader, after his death he became, as engraved in his tombstone epitaph in New York, the "legende [legend] of the Jewish labour movement." ${ }^{7}$ He was born in Latvia, then part of Czarist Russia, to a Christian Lutheran middle-class family of Jewish origin, and spent most of his childhood and youth in Minsk (now Belarus). Despite his later prominence in Jewish politics, as an adult Medem never saw the need to undergo a religious conversion to Judaism, since for him (and for the Bund) Yidishkayt (Jewish/Yiddish culture), and not religion, was the main element that defined the (Eastern European) Jewish nation. ${ }^{8}$ As a university student in Kiev, Medem became involved in revolutionary politics and joined the newly founded Russian Social Democratic Workers' Party (RSDRP). Back in Minsk, Medem was exposed to Jewish culture and life and developed, as he later stated in his memoirs, "a warm feeling for Jewishness" (Medem, 1979: 263) and a profound sympathy for the suffering of Jewish workers. In consequence he became active in the Bund, at the time the Jewish section of the RSDRP. Medem was one of the Bundist delegates at the Second Congress of the RSDRP (1903), in which Lenin and the Iskra group mounted a frontal attack on the Bund that caused it to

${ }^{5}$ I thank Dr. Pickhan for allowing me to read this paper. See also Nimni (1999).

${ }^{6}$ Founded in Vilna in October 1897, der algemeyner yidisher arbeter-bund in Rusland, Lite un Poyln (the General Jewish Labour Federation [Bund] in Russia Lithuania and Poland) was suppressed in the Soviet Union - like all the other non-Bolshevik socialist parties - after the Civil War that followed the October Revolution, but it continued as an independent party in Poland throughout the interwar period. It achieved two peaks of popularity: the first at the time of the 1905 Revolution in Russia and the second just before the outbreak of the Second World War when it received about a third of the total votes cast for Jewish parties in the municipal and communal elections held between 1936 and 1939 (Frankel, 1981; Tobias, 1972; Mishkinsky, 1981; Gechtman, 2005b).

${ }^{7}$ On Medem's legendary status within the movement, see Mishkinsky (2004). Mishkinsky surprisingly claims that Vladimir Kossovsky, rather than Medem, was the "Bund's real theorist of the national question" (155), but he does not offer evidence to support this argument, which runs counter to the views of both activists at the time and later scholars (including Kossovsky himself). See Kossovsky (1943).

${ }^{8}$ The fact that Medem, the most venerated Bundist leader, was a non-Jew according to the religious Jewish law, since both his parents had converted to Christianity and he himself was baptized as a child, is a phenomenon almost without parallel in Jewish organizations. The only comparable example that comes to mind is that of Rudolf Rocker (1873-1958), a non-Jewish German émigré in the early twentieth century who, to agitate the workers, mastered Yiddish to such an extent that he became the main leader among Jewish anarchists in London and later in New York (Rocker, 1956; 1998). 


\section{National-Cultural Autonomy and 'Neutralism': Vladimir Medem's Marxist Analysis of the National Question, 1903-1920}

withdraw from the RSDRP for three years. Later at the same congress (that lasted several weeks) the RSDRP split into Bolsheviks and Mensheviks. From that point on, Medem maintained a critical attitude toward Bolshevism, which Lenin reciprocated with frequent vitriolic attacks against the Bund and against Medem himself. Medem's disapproval of communism increased after the October 1917 Revolution, which he deemed adventurist and authoritarian.

Medem's cosmopolitan experience and outlook, together with his personal decision to join a national (Jewish) party, contributed to his growing interest in the national question. Of his many theoretical, polemical, journalistic and autobiographical writings, the most influential was his 1904 pamphlet Social Democracy and the National Question, which earned him recognition as the Bundist authority on the issue (Medem, 1943). ${ }^{9}$ Medem's goal was not just to outline a political program to deal with the specific practical problems the Bund confronted at the time but to establish the foundations for a comprehensive theoretical analysis of the nation from a social democratic (ie. Marxist) perspective that would serve as a basis for the Bund's program (Medem, 1979). His proposals echoed those advanced by Karl Renner and by the South Slav delegation at the Brünn Congress of the All-Austrian Social Democratic Party (Gesamtpartei) in 1899, but preceded the work of Otto Bauer, whose analysis and programmatic proposals were very similar to Medem's, with the important exception that Bauer explicitly excluded the European Jews from the status of nation (Bauer, 2000; Kogan, 1949; Gechtman, 2005a). In opposition to the solution proposed by nationalist thinkers and movements - the creation of separate nation-states for each national community- Medem, Renner and Bauer put forward a model of a 'state of nationalities'. According to Medem, some nations (ie. national groups)

are connected to one another in their economic and political life, and are intermingled with one another in one territory and cannot even think of political independence. This is a state of nationalities [a natsionaliteten-melukhe]. And here the question is as follows: how to ensure that the different nations live in peace with one another; what arrangement would prevent conflicts so that the stronger nation does not asphyxiate the weaker one (1943: 197-198).

Medem thus contrasted 'nation state' [natsonale melukhe or melukhe-natsie] and 'state of nationalities' [natsionaliteten melukhe]. In the latter, 'nationality' must be detached from 'citizenship'. In a state of nationalities officially recognized as such, no nationality would have an advantage over the others or be privileged by the state because citizenship would be nationally neutral and granted equally to the members of all nationalities. The nationalist attempt to divide Central and Eastern European nations into separate states was an artificial move, since these groups had been living in close contact with one another

\footnotetext{
${ }^{9}$ Other writings of Medem on the national question include Medem (1918a; 1918b), "Di alveltlekhe yudishe natsie," in Medem (1918c: 80-111), and "Farvos ikh bin gegen tsienizm," Di naye velt in Medem (1920: 12). See also Kossovsky (1943).
} 
for centuries, and it carried a high political and economic cost, since the different nations were dependent on each other in various ways.

While the term nationalism carried almost without exception a negative value in Bundist rhetoric in general and in Medem's work in particular, Medem maintained a neutral attitude toward national identity. On the one hand, social democrats must actively oppose all forms of oppression, and therefore must defend the smaller and weaker nations from being exploited or excluded by the larger ones. On the other, for Medem social democrats need not actively prevent the assimilation of the national minorities (Jews and others) into the dominant national culture (this is Medem's theory of 'neutralism'). Medem's position was that to prevent or end the oppression and forced assimilation of national minorities, it would not be enough to grant equal civil rights to members of all nations. The state must take an active role in the protection of minorities by granting each of them, as a collective, a national-cultural autonomy, that is, a non-territorial governing body with jurisdiction limited to the self-administration of cultural matters. A national-cultural autonomy would make it possible for the members of the minorities to decide more freely whether they wished to acculturate or keep their own culture. Denying the minorities autonomy rights in fact gave an advantage to the majorities seeking to impose their culture, especially through their control of the state apparatus. Thus even though for Medem the national question was "not the main problem, but one of the many questions related to oppression in general" (1943: 193), the resolve to address this question by finding an alternative to both nationalism and assimilationism shaped the Bundist program and created a new tension between the claims of working-class internationalism and national identity.

\section{The Bund, Medem, and the National Question}

Medem joined the Bundist debate on the national question midway. His first appearance (at the age of twenty-three) at an important Bundist meeting, the party's Fifth Congress held in Zürich in June 1903, produced a lasting impression. The Bund, and the revolutionary circles of Jewish workers in Vilna that preceded its foundation in 1897, had been for over a decade informally dealing with some of the issues implicit in the term 'national question' as the party attempted to define its own character as a movement of Jewish workers. The national question began to be officially debated at the Bund's Third Congress (1899) and in 1901, at the Fourth Congress, the party had adopted, after much discussion, an early version of the program of national-cultural autonomy. Jonathan Frankel, the foremost historian of the Jewish Labour movement in its Russian and social-democratic contexts, maintains that "according to strict logic, the Fifth Congress should have produced a schism in the Bund" (Frankel, 1981: 240). This opinion is fully justified by the minutes of the twelvehour debate on the national question, which reveal the deep ideological division between Bundists favouring internationalist and national stands. The disagreement on whether Jews should demand collective rights in addition to individual civil rights was even more 


\section{National-Cultural Autonomy and 'Neutralism': Vladimir Medem's Marxist Analysis of the National Question, 1903-1920}

pronounced than in previous congresses and a compromise seemed impossible. Different solutions were proposed, contingent on what the various participants in the congress thought would happen to the Jewish workers in the future, what in their estimation would be the desirable outcome, and what, given these tendencies, would be the best way to defend their interests. ${ }^{10}$

The long discussion of the national question at the Fifth Congress revolved around a motion proposed by Medem, whose precise text is now lost (Tobias, 1972). He set the tone of the debate, framing it in theoretical terms, and presented the views he would later develop in his published articles. In his presentation, Medem - who appears as 'Vinitski' in the minutes - insisted that social democracy must provide a reasonable answer to the national question (in general, not just with regard to the specific challenges his party confronted at that point in history). He considered three possible directions, two of which he dismissed out of hand: nationalism and assimilationism. The third direction, the one he identified with social democracy, was to hold a neutral attitude towards each and every national collective. That meant to let "each given group solve the [national] question in its own way" (Di diskusie, 1927a: 92). The question whether the Eastern European Jews or any other minority would persist or assimilate into dominant cultures could not be decided in advance but would be determined by historical (social and economic) factors. (Medem's own prediction was that Jewish national culture and identity would continue to exist in the future after the democratic and proletarian revolutions.) For Medem, national identity [ongeherikayt] was not important in itself but it was nonetheless necessary to defend weaker nations from majority oppression. The aim of the program of national-cultural autonomy was to prevent coerced assimilation. Therefore, Medem rejected nationalism but not national identity; he rejected 'assimilationism' but adopted a neutral position regarding assimilation itself. This is the position known as 'neutralism', the most original product of the Bund's Fifth Congress (Di diskusie, 1927a; Tobias, 1972; Frankel, 1981).

Medem's neutralist views were opposed by several intransigent 'internationalist' delegates, who demanded that the Bund adhere to a strictly cosmopolitan position and limit its activities to representing the Yiddish-speaking workers without expressing any separate demands for Jews. They contended that the Bund's 1901 resolution in support of nationalcultural autonomy for Jews had been adopted in haste; some even claimed that it had been adopted under the influence of (Polish and Jewish) nationalists: the Zionists and the Polish Socialist Party (Polska Partja Socjalistyczna). ${ }^{11}$ For these delegates, it was not

\footnotetext{
${ }^{10}$ The minutes of the debate on the national question at the Bund's Fifth Congress were published in 1927 and 1928. See Di diskusie (1927a, 1927b; 1928). On the Bund's intricate dealings with Polish socialism and the Polska Partja Socjalistyczna, see Hertz (1969); Mishkinsky (1981); and Zimmerman (2004).

${ }^{11}$ Mark Liber, the most nationally oriented representative participating in the Fifth Congress, urged that a socialist answer be given to the Jewish national question, because otherwise the Zionist proposals would be the only ones available to the Jewish masses. For the internationalists, this claim confirmed their suspicions (Di diskusie, 1927b).
} 


\section{National-Cultural Autonomy and 'Neutralism': Vladimir Medem's Marxist Analysis of the National Question, 1903-1920}

necessary to demand more than equal civic rights for all citizens (including Jews). The most vocal internationalist delegates, Sholom Levin and Tsemakh Kopelzon ('Timofei' in the minutes), predicted that the Jews' future was assimilation rather than cultural or national rebirth (Di diskusie, 1927a). Following Marx and Engels, Kopelzon argued that the Eastern European Jews, a 'non-historical' nation, would eventually assimilate into the dominant Russian culture (which he considered to be "international culture in a Russian form"), just as the Jews in the West were then undergoing a process of assimilation (Di diskusie, 1927a: 88). Kopelzon believed that Jews' assimilation was not only unavoidable but also desirable. The program of national-cultural autonomy was unnecessary; indeed, when discriminatory laws against Jews were abolished, the Bund itself would disappear. Moreover, if Lithuanians, Jews, Byelorussians, Poles, and other nationalities within the social democratic movement were to adopt a national program that fit each individual group, that would only bring conflict into the ranks of the working class instead of advancing the workers' common goals (Di diskusie, 1927a). (In response, Tsivia Hurvitsh, the most renowned Bundist activist from Łódź, claimed that the program of national autonomy would not separate the Jewish working class from the other nations' workers; on the contrary, Jewish workers would inspire more respect from their non-Jewish peers (Di diskusie, 1928). ${ }^{12}$

In Sholom Levin's view, national-cultural autonomy would hinder the chances of the Jews' successfully adopting the culture of the general (Russian) population; for him, the main problem Russian Jewish workers confronted was precisely their lack of freedom to assimilate. Levin reminded the audience at the congress that national-cultural autonomies could not be established in Russia before a democratic regime, and by then they would be unnecessary. The rights and freedoms that would ensue-free press, the right to teach in the spoken language, etc. - would be sufficient, thus cancelling the need for national autonomy (Di diskusie, 1927a; 1928). Levin's assessment directly contradicted the forecast of the autonomist delegates, like Hurvitsh, who held that a bourgeois democratic republic would offer individual equal rights but would not end the oppression of national minorities as collectives, and thus the need for legal arrangements that would allow national minorities to manage their own cultural issues would not cease (Di diskusie, 1928).

While it was implied in the internationalists' interventions that they accepted the notion that Eastern European Jews were a nation, they valued international above national solidarity. Another internationalist delegate, Isai Aizenshtat (who in the minutes appears under the pseudonym Vitalii Yudin), further criticized Medem, claiming that the demand for autonomy kindled nationalist aspirations. Aizenshtat insinuated that there was a serious contradiction between Medem's alleged neutralism and the voluntaristic demand to institutionalize national rights and promote national culture (Di diskusie, 1927a; 1928). Most internationalists agreed with Aizenshtat that the Bund should not develop a national program but should address the national question only in the context of the Russian social

${ }^{12}$ On Hurvitsh, see Samuś (2001). 


\section{National-Cultural Autonomy and 'Neutralism': Vladimir Medem's Marxist Analysis of the National Question, 1903-1920}

democratic party. Dovid Kats (who had opposed the adoption of the national program in the previous congresses as well) asserted that the establishment of a national-cultural autonomy, far from being a progressive development, would constitute a regression to medieval consuetudinary law [gevoynhayt rekht], that is, a system based on custom, usage and tradition which, moreover, was dangerously connected to religion. It would be very unwise to introduce such remnants of the past into the legal systems of the future. Kats insisted that the Bund must resist national demands just as it resisted religion, because both were equally reactionary (Di diskusie, 1928). ${ }^{13}$

The long discussion ended in deadlock. The delegates at the Bund's Fifth Congress were unable to reach a consensus that would have allowed them to develop the hesitant and vague resolution on national-cultural autonomy adopted at the previous congress (1901) (Frankel, 1981; Tobias, 1972).

\section{Medem on National-Cultural Autonomy and Neutralism}

The internal Bundist debate on the national question at the Fifth Congress in June 1903 took place under the shadow of the upcoming Second Congress of the RSDRP, which opened later that month in Brussels (and later continued in London). The imminence of the Second Congress had generated acute tensions in the RSDRP regarding its internal organization and the widespread expectation that Lenin and his supporters (organized around the Iskra journal) would take over the party. For several months, Iskra had maintained a fierce offensive against the Bund, and in particular against its autonomous status within the Russian party. The question confronting the Second Congress seemed merely organizational, but it had significant ramifications: the autonomy of the Bund within the RSDRP could not be separated from the national-cultural autonomy of the Jews and other national minorities in the future socialist Russia. Furthermore, recognizing the autonomous status of the Bund and other organizations inside the RSDRP implied a federal structure, which was exactly the opposite of what Lenin had been promoting since the publication of What Is to Be Done? a year earlier (Lenin, 1961). When the Bund delegates arrived at the Second Congress and found that the Bund's status in the RSDRP was to be the first topic on the agenda, they were taken completely by surprise. The outcome of the discussion was that the Bund was pushed out of the RSDRP against its will for three years, and the RSDRP split between Mensheviks and Bolsheviks. ${ }^{14}$ Following these turbulent events, many individual Jewish socialists, in particular those who sympathized with the Bolsheviks' uncompromising revolutionary positions, were forced to reconsider whether their loyalty belonged to the Bund or to the all-Russian revolutionary movement. In turn, the Bund as a party was forced to clarify its position within the revolutionary movement.

\footnotetext{
${ }^{13}$ Curiously, in his programmatic discussion of the legal basis for national-cultural autonomy and collective national rights, Renner explicitly resorted to language reminiscent of medieval consuetudinary law, claiming that the national-cultural autonomy would be a 'corporation' (2005; Gechtman, 2005a).

${ }^{14}$ For a detailed account of the role the Bund played in the debates at the Second Congress of the RSDRP, see Frankel (1981).
} 


\section{National-Cultural Autonomy and 'Neutralism': Vladimir Medem's Marxist Analysis of the National Question, 1903-1920}

As part of this process, Medem set out to publish systematically his views on the national question. His extensive article Social Democracy and the National Question (1904) was motivated not only by the practical concerns of his party but also by his dissatisfaction with the scant attention the national question had so far received in social-democratic literature. ${ }^{15}$ From the many arguments Bundists in Russia and abroad had had, not only among themselves and with other Russian social democrats but also with Polish socialists, Russian Populists (Social Revolutionaries (SRs)) and Zionists, Medem had concluded that the wording of the program of national-cultural autonomy in the resolution of the Bund's Fourth Congress "left much to be desired" and its "theoretical justification had not yet been adequately elaborated" (1979: 263). This made visible the "pressing need to arrive at a firm viewpoint, a genuine socialist perspective on this major and intricate problem" (Medem, 1979: 263). Medem deplored the low quality of the available Marxist analyses of the issue ${ }^{16}$ and, what was even worse, their unwitting reiteration of "ideas and feelings that rule in the bourgeois world and that [thus] find their way into the proletarian camp." Some of these writings "echo[ed] nationalist tones" and used a "terminology and slogans that carry a clear bourgeois stamp" (Medem, 1943: 173) ${ }^{17}$ As an alternative, Medem proposed an analysis of the national question according to the logic of class struggle and the development of class-consciousness. The social democratic position must reflect the true interests of the working class and be consistent with its internationalist character. For Medem, class struggle was not the main principle of social democracy, but its only principle. The working class was not interested in conquering foreign markets or control the domestic ones, thus its true interests did not coincide with those of the nationalist or assimilationist bourgeoisie (Medem, 1943).

In this article, Medem reaffirmed his indictment against nationalism and what he saw as its twin phenomenon: assimilationism. He candidly confessed:

As far back as my student years in Kiev, I had retained a sharply negative attitude
toward nationalistic aspirations and appetites. I passionately hated the very word
"nationalist." On the other side, the assimilationist school of thought, especially in
the form in which it exulted in the columns of Iskra, had aroused profound distaste in

${ }^{15}$ The article was fist published in Russian in 1904, and later translated into Yiddish as Di natsionalye frage un di sotsial demokratsie (Vilne, 1906) and reprinted several times in different editions. The edition I am citing here (Medem, 1943) is the best and most comprehensive Yiddish translation available.

16 "Such mental confusion is not the result of the complexity and intricacy of the question itself [ot der bilbl-hamoykhes iz nisht azoy der rezultat fun der farviklkayt un farplontertkayt fun der frage gufa]" but of "the complexity and intricacy" with which these theorists have treated the question (Medem, 1943: 173). To be sure, as stated above, Medem did appreciate the work of Renner, and would later appreciate that of Bauer, despite some disagreements with the latter on the status of the Jews as a nation. On Medem's reaction to Bauer's work, see Gechtman (2005a).

${ }^{17}$ Here Medem is implicitly criticizing Lenin's consistent defence of the 'right of nations to selfdetermination', a position identical to that of most liberals and nationalists; see Gechtman (2005b, chapter 4). 


\section{National-Cultural Autonomy and 'Neutralism': Vladimir Medem's Marxist Analysis of the National Question, 1903-1920}

me. Besides all this, I had imbibed, in the drab little Jewish streets of Minsk, a warm feeling for Jewishness; but in the maturing of a deeper awareness, the foregoing represented as yet only raw material (1979: 263).

The full complexity of the national question was manifested not in areas inhabited by one nation only - which, in fact, was very rarely the case, especially in Eastern Europebut in regions where several nations were "connected to one another in their economic and political life" (Medem, 1943: 197). Medem predicted that the dismemberment of multinational states by creating several nation states would not solve the national question; on the contrary, it would aggravate it in each one of the new states and increase the tensions among them.

Medem analyzed the nation as a social and historical phenomenon. The nation was nothing more than "the sum of all the individuals who belong to a determined historic-cultural group, independently of whether they live in various territories" (Medem, 1943: 219). In this way, Medem determinedly separated the territorial from the national question since in most cases even nations identified with a defined area did not control all their territory but shared it with other nations. He denied the existence of the nation as "an independent thing," entity or body, or as "a closed circle with fixed contents," as nationalists claimed (1943:188). It was rather something more subtle, a shade or 'colour' that modified other, more concrete bodies: states, classes, institutions, and so on. National culture was merely the

typical form in which the general human content takes shape. The content of the cultural life, which is the same everywhere, assumes various colours, various national forms, since it belongs to different groups with different social relations. (Medem, 1943: 187-188)

Hence, in Medem's definition national culture was the particular cultural form that shapes or modifies a content which in itself was not particular but shared by all peoples - a red chair, a blue chair, a stool, a sofa, all have the same 'function'. While the content is everywhere the same, the historical relations in a particular community give rise to the specific cultural forms. With time, a community develops the particular colour of its national culture: "the body is the same, the external skin is different" (Medem, 1943: 188-189). In modern societies, it was the bourgeoisie of the ruling nation that imposed its particular culture on state institutions, or, following Medem's image, painted the state with its own national colours (Medem, 1943).

Medem's definition of nation was in direct contradiction to that of nationalist theorists of the nation, such as the famous statement by the French nationalist Ernest Renan: 


\section{National-Cultural Autonomy and 'Neutralism': Vladimir Medem's Marxist Analysis of the National Question, 1903-1920}

a nation is a great solid unit, formed by the realization of sacrifices in the past, as well as those one is prepared to make in the future.... To share the glories of the past, and a common will in the present; to have done great deeds together, and to desire to do more - these are the essential conditions of a people's being (quoted in Medem, 1943: 185-186; as translated in Renan, 1995: 153-54). ${ }^{18}$

For Medem, this "high-sounding and empty rhetoric [hoykhe un puste melitse]" showed "clear as daylight what the bourgeoisie preached": behind the call for national solidarity and sacrifice lay the bourgeoisie's interests, which allegedly represented the interests of the entire population but in practice defended only its own business. The bourgeois class used the notion of national solidarity to conceal the class struggle between the working class and the bourgeoisie and thus facilitate "the spiritual and material enslavement of the proletariat" (Medem, 1943: 186). The politics of the bourgeois, both in the assimilationist and in the nationalist tendencies, are the same: they make pronouncements about the destiny of the whole nation but in fact they care only about their own class interests.

While national culture for Medem was just a particular shape with a neutral value, nationalism was a very different phenomenon than the nation (or national culture) itself. Nationalism took two main forms: the form of oppression and the form of a struggle for liberation, and both versions had much in common (Medem, 1918a). While each one represented opposing interests (the interests of different national bourgeoisies), in practice both nationalisms shared similar characteristics and to a certain extent similar goals. The nationalism of the oppressive nation represented a successful attempt by a national bourgeoisie to control the market and limit 'foreigners' by means of social and administrative restrictions established through their control of the state apparatus. In reaction, the bourgeoisie of the oppressed nations, excluded from the state apparatus, tried to control a sector of the market by appealing to the rhetoric of national struggle. In this way, nationalist ideology and the cult of the 'national spirit' (gayst) masked commercial interest and the desire to control the market of material or cultural products. The only real goal for the nationalists was the victory of their language and culture as a means to increase economic control. The fight for commodities and resources was wrapped up in the myth of a higher national ideal. Medem claimed that there was no essential difference between the two types of nationalism except that between their relative political and economic power. The difference between the nationalism of the ruling and that of the oppressed nations "is merely external; give the government to the other nation, and you would change also their politics and roles" (Medem, 1943: 180) ${ }^{19}$

\footnotetext{
${ }^{18}$ Medem, of course, did not have in mind the struggle for liberation of colonial nations but rather European nations under foreign control such as the Poles and the Czechs, though some interesting parallels can be found in Franz Fanon's characterization of the 'national middle class' and the 'nationalist parties' in the colonial setting. See Fanon (1968).

${ }^{19}$ To illustrate this point, Medem discussed the same example that Bauer would later analyze in more detail: that of the Germans and the Czechs (Bauer, 2000).
} 


\section{National-Cultural Autonomy and 'Neutralism': Vladimir Medem's Marxist Analysis of the National Question, 1903-1920}

For Medem, class conditions dictated different types of nationalism. The boastful and arrogant nationalism endorsed by the bourgeoisie of imperialist nations, for example, used empty imperialist slogans about its historical mission to bring civilization to the world while relying mainly on its military and naval power. On the other hand, Medem (like many other Marxists) was particularly dismissive of the defensive nationalism of the petitbourgeoisie. His economic security constantly threatened by big capital, and fearful of a future that he could not control, the petit-bourgeois nationalist held on to an idealized vision of a bygone age. Those grandiose dreams helped him forget the reality of the unfavourable economic conditions to which his class was condemned:

He wraps his class interests in the veil of national demands, yet he does not possess even the power to fight for those demands; he can only fantasize about them. He cannot look at life right in the eyes; he is weak, exhausted, frightened, he is afraid of life. He dreams. He dreams of independence and freedom; he dreams of his own territory, in which he will obtain his own culture - his own market. He is impressed by nationalist slogans, disguising his own weakness and political bankruptcy with high-sounding and empty metaphors (1943: 183)

Medem's conclusions on nationalism were categorical:

the colours are different, the essence is the same. This essence - worshipping and kneeling to one's own nationality; 'ours' is a temple, 'foreign' does not count ... The national interest and the national property - that is the foundation of the whole socio-political edifice. This is the common characteristic of nationalism, grounding all its forms; it is common to Bismarck and Dubnow, Rochefort and Ahad Haam. (1943: 183-184) 20

Medem's choice of examples is meaningful: even the most moderate Jewish nationalists, whose arguments appeared most reasonable, were in essence indistinguishable from the most fanatic, aggressive and militaristic non-Jewish nationalists. Change their place and relative power, and their specific ideologies would also change.

\footnotetext{
${ }^{20}$ Otto von Bismarck (1815-1898), Kanzler of Prussia (1862-1890) and of all Germany (1871-1890), was (by the time Medem wrote his treatise) the most aggressive exponent of German nationalism. Bismarck's well-known pronouncement that "the great questions of the day will not be decided by speeches and the resolutions of majorities ... but by blood and iron" was indeed translated into action and he became the architect of German unification in 1871 as a result of a series of bloody wars (1862). Victor Henri, Marquis de Rochefort-Luçay (1831-1913), French journalist and politician, was an enthusiastic supporter of the Paris Commune. Later on he switched to the extreme nationalist right and supported Georges Boulanger's failed coup of 1889. During the Dreyfus Affair, Rochefort was one of the founders of the short-lived French Nationalist Party which orchestrated the attacks against Alfred Dreyfus and other minorities (Jews, Freemasons, Protestants, Germans, etc.). Ahad Haam (Hebrew for "one of the people," pseudonym of Asher Ginsberg, 1856-1927) and Simon Dubnow (1860-1941) were the most moderate proponents of Jewish nationalism. Ahad Haam was the ideologist of 'cultural Zionism', a minority group within Zionism that did not demand Jewish
} 


\section{National-Cultural Autonomy and 'Neutralism': Vladimir Medem's Marxist Analysis of the National Question, 1903-1920}

Medem's indictment of nationalism was complemented by his harsh condemnation of 'assimilationism' (the active promotion of assimilation). According to Medem, both tendencies responded to the bourgeoisie's interests: "nationalism captured all the peoples; the assimilationist tendency is so far a rare fruit that flowers nowhere so strongly as in Jewish soil" (Medem, 1943: 175). Both ideologies reflected the bourgeoisie's economic interest in controlling, or at least having a greater share of, the market in a certain area. Assimilationism stemmed from the ideas of emancipation and equal civil rights. By struggling to erase the privileges of estate and religion in the feudal mode of production, the bourgeoisie promoted the free participation of all capital owners in a pure economic competition without interference from alien elements. Therefore, in order to obtain their share of the wealth produced by the market, many members of the Jewish bourgeoisie had adopted the dominant culture (Medem, 1943). As a result, this is what Medem concluded concerning the Jewish people:

It may still be the verdict of history that Jews will assimilate into other peoples. For our part, we will not deploy any forces to stop this process nor to encourage it. We do not interfere with it. We are neutral. ... We are not against assimilation; we are against the pursuit of assimilation, against assimilation as a purpose. ... Should history want the Jews to develop into an independent culture, we will not try to interfere with this process either; we will not care for its success nor interfere with it; we are neutral (1943: 189).

This is an elaboration of the neutralist doctrine that Medem had first presented orally at the Bund's Fifth Congress. Medem's neutralism was never formally adopted by the Bund, and indeed it was overtly rejected from around 1910, when the Bundist movement became increasingly involved in the promotion of Yiddish secular culture. ${ }^{21}$ Medem himself nevertheless retained the status of chief theorist on the national question, and his views, including his texts promoting neutralism, continued to be published in the party press.22

sovereignty in Palestine (at least not in the short term) but rather the creation of a Jewish cultural centre that would inspire a revival of Jewish national life in the 'Diaspora'. Dubnow, a prominent Jewish historian and the best known leader of 'Diaspora nationalism', believed that the worldwide Jewish community was a single nation; however, the Jews were so advanced in relation to other nations that they had transcended the need for a common territory and sovereign state, and thus could realize their national aspirations through autonomous communities within other states (Taylor, 1955; Williams, 1966; Simon; 1960; Dubnow, 1958).

${ }^{21}$ According to Mishkinsky (2004), the idea of neutralism was only the product of circumstantial conditions, mainly the Bund's simultaneous struggle against the Bolsheviks, the Polish socialists and the Zionists. In my view, Mishkinsky puts too much stress on the Bund's belonging to the Jewish collective and its national identity, and consequently tends to overemphasize the Bund's debates with Zionism. A careful reading of the sources shows that Bundists referred to Zionism sporadically and usually dismissively, while devoting much more time and energy to debates with other socialists. Medem, I believe, was sincere in his thorough attempt to address his own national culture from a social-democratic rather than nationalist perspective. I discussed the Bund's promotion of proletarian culture in Gechtman (1999). 


\section{National-Cultural Autonomy and 'Neutralism': Vladimir Medem's Marxist Analysis of the National Question, 1903-1920}

Medem found it particularly puzzling that despite the fact that political separatism (the demand for independent nation-states) would only provide a partial solution to the national question in the state of nationalities, and benefit the bourgeoisie above all, the program of political separatism was becoming increasingly popular even among social democrats. Social democrats ought to stop conceiving the national question in terms of territorial independence and reconceptualize it in terms of the relation between nations (or nationalities) within one state. Medem's concern was the fact that 'bourgeois' stands - the nationalism of the oppressive and oppressed nations, and assimilationism - had found their way into the proletarian camp, indeed into his own party. For social democrats the question "what are the tasks of the nation?" was meaningless. The practical question, was, rather, what position must social democrats take regarding the national question? According to Medem, this position should not merely replicate the answer offered by the bourgeoisie. Social democrats must avoid participating in nationalism and supporting its politics as stated by the bourgeoisie: "emes [true], we are against the nationalists ... [but] we are not against the culture's national character, we are against nationalist politics" (Medem, 1943: 189-190). Workers should carry on their own struggle, wary of reactionary elements and bourgeois influence; then only will this struggle be truly liberating and progressive. In other words, "the working class should understand the fight against national oppression in the context of its more general struggle for liberation" (Medem, 1943: 191). As mentioned above, for Medem, the proletariat, unlike the bourgeoisie, had no ambition to gain control of domestic or international markets and thus its interests differed from those of the national bourgeoisie.

Still, social democrats must take the national question seriously because national oppression and restrictions on the use of the national language were particularly harmful to workers, as they had fewer opportunities to learn a language that was foreign to them. The national language, the workers' mother tongue, was the only means by which they could have access to education and information. If the oppressive (bourgeois) state limited them in that respect, then workers were effectively barred from cultural life. Furthermore, all their dealings with juridical and administrative bodies would have to be conducted in a foreign language (Medem, 1943). "Since national oppression has a detrimental effect on the situation of the working class, it delays its development and disrupts the class struggle," Medem concluded:

it is necessary to prevent any nation from being oppressed, as far as it is possible in the capitalist order. We must create the mechanisms that will guarantee each nation's complete freedom of cultural development and remove every element that oppresses or injures it (1943: 195).

\footnotetext{
${ }^{22}$ For example, Medem's article "Natsionalizm oder 'neytralism'," in which the doctrine of neutralism was further developed, continued to be reprinted and circulated long after this doctrine was officially rejected by the party. In the 1918 edition, Medem appended a short introduction in which he expressed some dissatisfaction with the term 'neutralism' itself, while still espousing the principle and its political implications (1918b: 112).
} 


\section{National-Cultural Autonomy and 'Neutralism': Vladimir Medem's Marxist Analysis of the National Question, 1903-1920}

However, insofar as the bourgeois order existed, there could not be any safeguards against any form of oppression, including national oppression. The minimum program (that is, the measures that could be implemented without a wholesale transformation of society) must endeavour to extract from the capitalist order the concessions that could be realistically expected from it, and nothing more. Believing that equal civil rights for individuals would end national oppression was, for Medem, a superstition (he equated the notion of equal civil rights to a talisman [kameye]). Any immediate demand (within the context of the existing order) could not deliver a "magical solution" to national oppression. To promise that the implementation of such immediate but limited measures would completely eradicate national oppression would be to create false hopes; such a promise would be as false as the social reformists' promise that they could establish social peace without first eliminating the capitalist mode of production (Medem, 1943: 196-197). In consequence, the social democratic program must contain not only negative demands (the abolition of inequalities) but also new, affirmative demands, such as the creation of an elected representative assembly for national minorities and the right to a 'national' (ie. cultural) education (Medem, 1943).

The function of proletarian parties such as the Bund, Medem insisted, was to keep the working class consciousness alive and to counteract the bourgeoisie's use of nationalist slogans to intensify national conflicts. "We should not forget," he wrote, that "consciousness of proletarian solidarity is not a given, ready-made thing that exists constantly and never changes" (Medem, 1943: 215-216). Indeed, the party's most important task was to strengthen class consciousness through education. ${ }^{23}$ The achievement of national-cultural autonomy would not only provide a desirable solution to the national question but would also free the proletarian party to pursue its most important tasks:

from a social democratic point of view, a constant and resolute struggle is required in favour of those political forms which would remove-already in the present order- the obstacles which interfere with the creation of a pure and clear proletarian class consciousness; and from this point of view, it would be an enormous mistake to pretend to ignore such obstacles [tsu makhn zikh ke-loyede'e vegn der ongevizener menyie] without even trying to remove them from our path. The main problem with the general-national-cultural arrangements

\footnotetext{
${ }^{23}$ Medem here assumes that class consciousness is not a ready-made 'thing' but requires conscious promotion and development. Compared to E.P. Thompson's understanding of class and class consciousness: "class is a relationship, and not a thing ... 'It' does not exist, either to have an ideal interest of consciousness, or to lie as a patient on the Adjustor's table. ... [W] cannot understand class unless we see it as a social and cultural formation, arising from processes which can only be studied as they work themselves out over a considerable historical period.... The class experience is largely determined by the productive relations into which men are born - or enter involuntarily. Class-consciousness is the way in which these experiences are handled in cultural terms ... If the experience appears as determined, class-consciousness does not" (Thompson, 1966: 11, 9-10). Medem's reference (in the next quotation) to a "pure and clear class consciousness" may however imply traces of the idealist approach that Thompson repudiates.
} 


\section{National-Cultural Autonomy and 'Neutralism': Vladimir Medem's Marxist Analysis of the National Question, 1903-1920}

lies in the fact that they feed the nationalist provocations (Medem, 1943: 216).

The last sentence is significant: for Medem, a clearly articulated national program would not only not make the Bund nationalist (as Lenin and others accused it of being at the time) but would actually free the Bund (and Russian social democracy in general) from nationalism. A widespread adoption of this program by social democrats would enable both the all-Russian party and each of the national parties to turn to more important tasks.

Following Renner and the South Slav delegation at the Brünn Congress of the Austrian Gesamtpartei in 1899, Medem proposed that each nation within the multinational state must be constitutionally granted the collective right to establish a national-cultural autonomy, that is a juridical and executive body whose exclusive purpose would be to direct its cultural affairs. It would be composed by authorities elected according to democratic principles through a general ballot. In order to be able to function in the context of the legal system of the modern state, this autonomous institution must be "recognized as a 'juridical person"” (Medem, 1943: 216-217). In this way the nation itself, as a recognized juridical body within the democratic state, would become "the only authority in the exclusive domain of those questions in which the national life manifests itself as such, that is in the realm of culture" (Medem, 1943: 217). What Medem proposed was a separation of powers, but within the context of the executive power - a division of functions in which the central and regional governing bodies would be in charge of general political, social and economic issues and the non-territorial national-cultural autonomies would be responsible for cultural issues. While the democratic, central institutions of the government would ensure equality of civil rights for all individuals, the autonomous institutions of national government would guarantee equal collective rights for all nations within the state. ${ }^{24}$

For Medem (and the Bund), national-cultural autonomy was the only adequate answer to the national question in Central and Eastern Europe, the only one that avoided the Scylla of nationalism and the Charybdis of assimilationism. Although federal arrangements and territorial self-government might reduce many of the evils of highly centralized regimes, they could never fully solve the problems of national minorities since "the concepts of 'nation' and 'population of a given territory' are not identical" (Medem, 1943: 218) Since even in territories primarily identified with a particular nation (e.g. Poland, Hungary, Romania) the actual population included members of other nations, territorial autonomy or independence could in the best case liberate from national oppression only the national majorities. For the rest of the nationalities, territorial self-government (autonomous or independent) could not be a satisfactory answer. Furthermore, Medem added, "the individual members of the ruling nation of the area are free insofar as they remain in 'their' province. Once they leave their area they are no longer free" (Medem, 1943: 218).

${ }^{24}$ On the relation between Medem's proposals and Renner's, see Gechtman (2005a: 28-31). 


\section{Header National-Cultural Autonomy and 'Neutralism': Vladimir Medem's Marxist Analysis of the National Question, 1903-1920}

Under the capitalist mode of production this situation would be increasingly common since large sectors of the population migrated in pursuit of employment, forcing many people to sever their connection with their ancestral territory. Many territories were losing their 'national colour' by either immigration or emigration, a tendency that resulted in a growing separation between nation and territory.

\section{Conclusion}

In the interwar period, the Bund (now located mainly in Poland) adopted the concept of national-cultural autonomy as one as the pillars of its ideology. Despite Medem's reputation as the recognized Bundist authority on the national question, his concept of neutralism was openly defied, ${ }^{25}$ mainly because it contradicted the Polish Bund's active promotion of Jewish and Yiddish cultural activities in this period. ${ }^{26}$ Still, this movement was not a form of nationalism because the Bund did not consider Jewish culture as something special, superior, 'chosen', that must be protected and preserved for eternity. ${ }^{27}$ Neither did Medem and the Bund demand for the Jews any form of sovereignty over any territory, but merely the collective right, for the Jews and every other national group, to control their cultural affairs. ${ }^{28}$ Furthermore, the vast Bundist literature in Yiddish reveals a consistent commitment to internationalism over national solidarity, manifested in a constant attempt to collaborate and find political common ground with proletarian groups of other nations while rejecting any alliance with bourgeois, nationalist or religious organizations, Jewish or not.

One of many instances of the Bundist attitude toward Jewish nationalism may be found in an article by Henryk Erlich (one of the main leaders of the Polish Bund in interwar Poland) published in May 1933 and appropriately titled "Neyn, mir zeynen nisht kayn ato bokhartonu folk!" [No, We are Not the Chosen People!] (Erlich, 1951). ${ }^{29}$ For Erlich, like for Medem, Jews were not the chosen people but were subjected exactly to the same

${ }^{25}$ During the Sixth Congress of the Polish Bund in 1935, Yoysef Leszczyński, one of the leaders of the left wing of the Polish Bund, referred to neutralism as "a road to active assimilation that should be fought with an active national-cultural effort with a socialist content," a bold statement considering Medem's status in the party at that time (Dubnow-Erlich, 1958: 172; conf. Blatman, 2001: 205).

${ }^{26}$ In the 1920s and 1930s, as the Bund became more involved in the organization of cultural activities in cooperation with members of other workers' groups and parties, the Yiddish language and Yiddish culture acquired an increasingly higher intrinsic value, as opposed to the merely instrumental value they had in the early years of the Bundist movement; I discuss these developments in Gechtman (2005b, chapter 7).

${ }^{27}$ According to Miroslav Hroch's definition, nationalism is "that outlook which gives an absolute priority to the values of the nation over all other values and interests" (Hroch, 1993, p. 6: emphasis in the original).

${ }^{28}$ Ernest Gellner's definition: "Nationalism' is primarily a political principle, which holds that the political and national unit should be congruent," that is, that each national group must have its own sovereign state (Gellner, 1994: 1).

${ }^{29}$ Originally published in the Bund's daily newspaper in Warsaw, Naye Folkstsaytung in May 1933. The Yiddish title is very eloquent: ato bokhartonu means literally "Thou hast chosen us," a phrase that appears in many Jewish prayers. Erlich rejected this belief with an emphatic triple negation: neyn, nisht and kayn. On the Naye Folkstsaytung, see Gechtman (2000). 


\section{National-Cultural Autonomy and 'Neutralism': Vladimir Medem's Marxist Analysis of the National Question, 1903-1920}

historical, economic and social processes as all other peoples on earth. As proof, Erlich pointed to Jewish nationalism (Zionism), which, despite its claims that it was less bloodthirsty than the nationalism of other nations, was "as odious and disgusting" as other nationalisms, and given the right opportunity would show "teeth and nails, no less than the nationalisms of other peoples." ${ }^{30}$ Observing his fellow nationals' nationalism removed any hope Erlich might have entertained about their alleged cultural, moral or intellectual superiority. Thus Erlich, as he faced the rise of fascism in the 1930s, continued to support the socialist and non-nationalist answer to the national question formulated by Medem and other Bundists at the beginning of the century and condemn all forms of nationalism, including the nationalism of the members of his own nation.

In the twenty-first century, both in Europe elsewhere, most states are defined as nationstates, to the extent that in everyday parlance the terms 'nation' and 'state' are often used interchangeably, even though in practice virtually every state is home to several or many cultures or nations. Moreover, national minorities generally expect that their oppressed status will be redressed if they take control over a circumscribed territory and create their own nation-state (rather than a more limited national-cultural autonomy within a multinational state); in turn, the dominant nations usually deny minorities both the right to secede and recognition of their collective rights within the existing state. In the past two decades the world has witnessed the partition and repartition of several multi-national states (think for instance of the former Soviet Union and Yugoslavia), while migration has greatly increased the national diversity of virtually all industrial and post-industrial societies. The centralist-atomist approach (Renner's terms; see Renner, 2005: 27-29; Gechtman 2005a: 26) of liberal theory, that recognizes the legal existence only of the state and the individual, greatly limits the ability of modern states to deal in legal terms with the existence of different collectives within their borders. ${ }^{31}$ In this sense, the insights and proposals formulated a century ago by Medem (and other Bundists) and the AustroMarxists deserve renewed attention. ${ }^{32}$

\footnotetext{
${ }^{30}$ Erlich wrote: "The Revisionist hooligan [ie. Jabotinsky] 'asserts' that Hitler's Germany did not impose such hardships on the Jews as the Soviet Union did [and for Jabotinsky] Hitlerism contains, inside its antisemitic shell, a more valuable core of anti-Marxism ... Jabotinsky is no more than a pocket-size Hitler, a fascist clown" (Erlich, 1951: 258).

${ }^{31}$ As evidenced during the recent debates on Canadian Prime Minister Stephen Harper's motion to grant the status of nation to the Québécois, many people find this idea troubling, in particular since nationalists (in this case, Québec sovereigntists) could use the legal recognition of their collective as a springboard toward secession. This was not Medem's (nor, for that matter, Renner's or Bauers') intention: their objective, as I claim in this article, was precisely to prevent the secession of national minorities and subdivision of states by creating the conditions for viable multinational / multicultural states (Official Report of the House of Commons, 2006a; 2006b).

${ }^{32}$ A full elaboration of the current theoretical and political relevance of Medem's ideas is beyond the scope of this article. Some social and political scientists, however, have been considering the contemporary relevance of national-cultural autonomy with increasing interest. For one of the most recent examples, see the excellent collection of articles accompanying the English translation of Renner's State and Nation, in Nimni (2005).
} 


\section{National-Cultural Autonomy and 'Neutralism': Vladimir Medem's Marxist Analysis of the National Question, 1903-1920}

\section{REFERENCES}

Bauer O. 2000. The Question of Nationalities and Social Democracy (1907, 1924). Edited by E. Nimni. Translated by J. O'Donnell. Minneapolis and London: University of Minnesota Press.

Bismarck. 1862. Speech to the Prussian Diet. 30 September, 1862. Online: http://germanhistorydocs.ghi-dc.org/pdf/eng/1_C_NS_Bismarck.pdf.

Blatman, D. 2001. "The National Ideology of the Bund in the Test of Anti-Semitism and the Holocaust, 1933-1947." In Jewish Politics in Eastern Europe: The Bund at 100. J. Jacobs (ed.). New York: New York University Press, pp. 197-212.

"Di diskusie vegn der natsionaler frage afn tsuzamenfor fun 'Bund', iuni 1903, Tsiurikh (fun di protokoln fun tsuzamenfor) (soyf), 'Unzer tsayt 2:1 (January 1928), pp. 83-96 [Diskusie 1928].

"Di diskusie vegn der natsionaler frage afn V tsuzamenfor fun 'Bund' iuni 1903 Tsiurikh (fun di protokoln fun tsuzamenfor)," Unzer tsayt: sotsialistishe khoydesh-shrift (Warsaw) 1:2 (November 1927), pp. 87-96 [Diskusie 1927a].

"Di diskusie vegn der natsionaler frage afn tsuzamenfor fun 'Bund', iuni, 1903, Tsiurikh (fun di protokoln fun tsuzamenfor)," Unzer tsayt 1:3/4 (December 1927), pp. 82-91 [Diskusie 1927b].

Dubnow-Erlich, S. 1958. "Yoysef Leshtshinski - zayn lebn un shafn." In Khmurnerbukh. Hodes, Leyvik, Leon Oler and Sophie Dubnow-Erlich (eds.). New York: Farlag Unzer Tsayt, pp. 45-177.

Dubnow, S. 1958. Nationalism and History: Essays on Old and New Jadaism. Philadelphia: The Jewish Publication Society of America.

Engels, F. 1849. “The Magyar Struggle.” In The Collected Works of Karl Marx and Frederick Engels. (1975). London: Lawrence and Wishart, Vol. 8, pp. 227-238

Engels, F. 1848. "The Frankfurt Assembly Debates the Polish Question.” In The Collected Works of Karl Marx and Frederick Engels. (1975) London: Lawrence and Wishart, Vol. 7, pp. 337-381.

Erlich, H. 1951. "Neyn, mir zeynen nisht kayn ato bokhartonu folk!” (May 1933). In Henryk Erlich un Viktor Alter. New York: Farlag Unzer Tsayt, pp. 256-258. 


\section{National-Cultural Autonomy and 'Neutralism': Vladimir Medem's Marxist Analysis of the National Question, 1903-1920}

Fanon, F. 1968. The Wretched of the Earth (1961). New York: Grove Press.

Frankel, J. 1981. Prophecy and Politics: Socialism, Nationalism and the Russian Jews, 1862-1917. Cambridge: Cambridge University Press.

Gechtman, R. 2005a. "Conceptualizing National-Cultural Autonomy: From the AustroMarxists to the Jewish Labor Bund." Jahrbuch des Simon-Dubnow-Instituts / Simon Dubnow Institute Yearbook, Vol. 4, pp. 17-49.

Gechtman, R. 2005b. 'Yidisher Sotsializm'. The Origin and Contexts of the Jewish Labor Bund's National Program, Ph.D. dissertation, New York University, New York.

Gechtman, R. 2000. "The Rise of the Bund as Reflected in the Naye Folkstsaytung, 19351936." Gal-Ed, Vol. 17, pp. 29-55.

Gechtman, R. 1999. "Socialist Mass Politics through Sport: The Bund's Morgnshtern in Poland, 1926-1939.” Journal of Sport History, Vol. 26, No.2, pp. 326-352.

Gellner, E. 1994. Nations and Nationalism. Ithaca NY: Cornell University Press.

Haupt, G., M. Lowy and C. Weill. 1974. Les marxistes et la question nationale, 18481914: Études et textes. Paris: François Maspero.

Haupt, G. and C. Weill. 1980. "Marx y Engels frente al problema de las naciones." In La cuestión nacional y la formación de los estados. G. Haupt and C. Weill (eds.) C. Ceretti (trans.). México D.F.: Cuadernos de Pasado y Presente, pp. 7-50.

Hertz, J. S. 1969. “The Bund's Nationality Program and Its Critics in the Russian, Polish and Austrian Socialist Movements." YIVO Annual of Jewish Social Studies Vol. 14, pp. 53-67.

Hroch, M. 1993. "From National Movement to the Fully-formed Nation: The NationBuilding Process in Europe," New Left Review, Vol. 198, pp. 3-20.

Kogan, A.G. 1949. "The Social Democrats and the Conflict of Nationalities in the Habsburg Monarchy," The Journal of Modern History, Vol. 21, No. 3, pp. 204-217.

Kossovsky, V. 1943. "Vladimir Medem un di natsionale frage" (1928). In Vladimir Medem: Tsum tsvantsikstn yortsayt. New York: Der Amerikaner Reprezentants fun Algemeynem Yidishn Arbeter-Bund ('Bund') in Poyln, pp. 130-140. 
Lenin, V.I. 1961. What Is to Be Done? (1902). In Collected Works. Moscow: Foreign Languages Publishing House, Vol. 5, pp. 347-529.

Medem, V. 1979. The Life and Soul of a Legendary Jewish Socialist: The Memoirs of Vladimir Medem (1923). New York: Ktav.

Medem, V. 1943. "Di sotsial-demokratie un di natsionale frage" (1904). Vladimir Medem: Tsum tsvantsikstn yortsayt. New York: New York: Der Amerikaner Reprezentants fun Algemeynem Yidishn Arbeter-Bund ('Bund') in Poyln, pp. 173-219.

Medem, V. 1920. "Farvos ikh bin gegen tsienizm." in Di naye velt. New York. 16 July, 1920, p. 12.

Medem, V. 1918a. "Natsionalizm, asimilatsie un sotsial-demokratie," in Zikhroynes un artiklen (Warsaw: 1918), pp. 64-80.

Medem, V. 1918b. "Natsionalizm oder 'neytralism'," in Zikhroynes un artiklen. Warsaw: Farlag Yudish, pp. 112-134.

Medem, V. 1918c. Zikhroynes un artiklen. Warsaw: Farlag Yudish.

Mishkinsky, Moshe. 2004. "Vladimir Medem: Ha’ish betn“uato" (1983). Iunim besotsializm hayehudi: Asufat ma'amarim. Beer Sheva: Makhon Ben Gurion, pp. 151-158.

Mishkinsky, Moshe. 1981. Reshit tnu'at hapo'alim hayehudit beRusya: Megamot yesod. Tel Aviv: Hakibbutz Hameuchad.

Mouffe, C. 1979. "Hegemony and Ideology in Gramsci." In Gramsci and Marxist Theory. C. Mouffe (ed.). London: Routledge and Kegan Paul, pp. 168-204.

Nimni, E. 2005. National Cultural Autonomy and Its Critics. London and New York: Routledge.

Nimni, E. 1999. "Nationalist Multiculturalism in Late Imperial Austria as a Critique of Contemporary Liberalism: The Case of Bauer and Renner." Journal of Political Ideologies, Vol. 4, pp. 289-314. 


\section{National-Cultural Autonomy and 'Neutralism': Vladimir Medem's Marxist Analysis of the National Question, 1903-1920}

Official Report of the House of Commons. 2006a. Dated November 24, 2006 (No. 086) Online: http://www2.parl.gc.ca/HousePublications/Publication.aspx?Language=E $\&$ Mode $=1 \&$ Parl $=39 \&$ Pub $=$ hansard $\&$ Ses $=1 \&$ DocId $=2539452 \&$ File $=0$

Official Report of the House of Commons. 2006b. Dated November 27, 2006 (No. 087). Online: http://www2.parl.gc.ca/HousePublications/Publication.aspx?Language=E $\&$ Mode $=1 \&$ Parl $=39 \& \mathrm{Pub}=$ hansard $\&$ Ses $=1 \&$ DocId $=2544166 \&$ File $=0 \#$ OOB 1798629

Pickhan, G. 2004. "Multiculturalism avant la lettre: The Bundist Minority Concept," unpublished paper read at the conference "From Pre-modern Corporation to Postmodern Pluralism: Diasporic Cultures and Institutions of the Jews between Empire and Nation State," Simon Dubnow Institute for Jewish History and Culture, Leipzig, 22-24, May 2004.

Renan, E. 1995. “What Is a Nation?” (1882). In The Nationalism Reader. O. Dahbour and M.R. Ishay (eds.). Atlantic Highlands NJ: Humanities Press, pp. 143-155.

Renner, K. 2005. State and Nation (1899). In National Cultural Autonomy and Its Critics. E. Nimni (ed.) London and New York: Routledge, pp. 15-47.

Rocker, R. 1998. Nationalism and Culture (1936). London: Black Rose Books.

Rocker, R. 1956. The London Years. London : Robert Anscombe \& Co. for the Rudolf Rocker Book Committee.

Samuś, P. 2001. “The Bund Organization in Lodz, 1898-1939.” In Jewish Politics in Eastern Europe: The Bund at 100. J. Jacobs (ed.). New York: New York University Press, pp. 90-111.

Simon, L. 1960. Ahad Ha-Am (Asher Ginzberg): A Bibliography. Philadelphia: The Jewish Publication Society of America.

Taylor, A.J.P. 1955. Bismarck: The Man and Statesman. New York: Scribner.

Thompson, E.P. 1966. The Making of the English Working Class. New York: Vintage Books.

Tobias, H.J. 1972. The Jewish Bund in Russia: From Its Origins to 1905. Stanford CA: Stanford University Press. 
Williams, R.L. 1966. Henri Rochefort: Prince of the Gutter Press. New York: Scribner.

Wolf, E.R. 1997. Europe and the People Without History. 2nd. ed. Berkeley: University of California Press.

Zimmerman, J. 2004. Poles, Jews and the Politics of Nationality: The Bund and the Polish Socialist Party in Late Tsarist Russia, 1892-1914. Madison, The University of Wisconsin Press. 